Jpn. J. Oral Biol., 32 : 323-329, 1990.

\title{
ORIGINAL
}

\section{Supernumerary postcanine teeth in the kuril seal (Phoca vitulina stejnegeri), the larga seal (Phoca largha) and the ribbon seal (Phoca fasciata)}

\author{
Masatsugu Suzuki, Noriyuki Ohtaishi and Fumiko Nakane \\ Department of Oral Anatomy I, School of Dentistry, Hokkaido University \\ Kita 13 Nishi 7, Kita-ku, Sapporo 060, Japan \\ 〔Accepted for publication: February 15, 1990]
}

Key words : Supernumerary teeth $/$ missing teeth / seal/splitting of tooth germ/atavism

\begin{abstract}
The supernumerary postcanine teeth were examined in the kuril seal (Phoca vitulina stejnegeri), the larga seal ( $P$. largha) and the ribbon seal ( $P$. fasciata). Supernumerary postcanine teeth were found in $6.56 \%, 6.03 \%$ and $11.76 \%$ of them respectively. On the other hand, $1.31 \%$ of the kuril seal, $0.86 \%$ of the larga seal and $11.76 \%$ of the ribbon seal were found to have missing teeth. So, in these three species, there is a greater percentage having supernumerary teeth than missing teeth. This is a rare situation in mammals because missing teeth are more common than supernumerary teeth in many species. As the position in which supernumerary postcanine teeth were found are commonly variable, it is thought that the cause of supernumerary postcanine teeth is due to a splitting of the tooth germ rather than atavism in the kuril seal and the larga seal. Also the positions of the supernumerary teeth in the kuril seal are different from the larga seal. This difference is presumed to stem from the differences in the foetal developmental process of the maxilla and mandible of the two species.
\end{abstract}

\section{Introduction}

It is widely known that many species of mammals, sometimes, have fewer or greater numbers of teeth than they are normally expected to have. This problem has been investigated for a long time. However, the cause of this abnormality of tooth number has not yet been clarified. Concerning the supernumerary teeth, Fujita" ${ }^{11}$ reviewed various studies about this and introduced two hypotheses. The first was the splitting of tooth germs and the second was atavism, and Fujita supported the former in the human. Also Wolsan ${ }^{21}$ proposed two interpretations of the origin of "extra teeth" in mammals. These interpretations are similar to Fujita's two hypotheses.

Colyer $^{31}$ investigated nine species of seals and found many cases of supernumerary teeth. Burns and $\mathrm{Fay}^{4}$ described that the most common abnormality of postcanine tooth number is supernumerary teeth in the ribbon seal. In general, there are fewer cases of supernumerary teeth than missing teeth in mammals ${ }^{3,5)}$, seals are the exception to this rule.

In this study, we have described the number and the position in which the supernumerary postcanine teeth occurred in three species of seals and made a comparison between these species. It has been said that seals have four premolars and one molar in each jaw ${ }^{6}$. However, due to the nearly homodont condition of these teeth, we refer to premolars and molars collectively as postcanine teeth, abbreviated as $\mathrm{PC}$, in agreement with King ${ }^{7)}$. So, for example, PC 1 means the first postcanine tooth. 


\section{Materials and Methods}

The skulls observed were those of 305 kuril seals, 116 larga seals and 34 ribbon seals. All were collected in the adjacent waters of eastern Hokkaido, and belong to the Kuril Seal Research Group (Obihiro University), Mr. Tetsuro Itoo (Asahi University) and Department of Oral Anatomy I, School of Dentistry, Hckkaido University. In all of the specimens, whether the supernumerary postcanine teeth occurred or not and the position in which they occurred were checked. All seals had shed their milk teeth and had erupted all permanent teeth.

In the ribbon seal, as the postcanine teeth were sparse and their shapes were similar, it was difficult to judge the position of the supernumerary teeth. Although a check was also made for missing teeth, it was not easy to judge whether the missing teeth were congenital or not. Therefore, the position of supernumerary teeth in the ribbon seal and missing teeth in all three species has not been dealt with much in this paper.

\section{Result}

$6.56 \%$ of the kuril seal, $6.03 \%$ of the larga seal and $11.76 \%$ of the ribbon seal had supernumerary postcanine teeth. Of all the three species, females rather than males tended to have a higher percentage. Notably in the ribbon seal, no male was found with supernumerary postcanine teeth. However, a high percentage of females $(28.57 \%)$ were found with them (Table 1). Specimens with missing teeth, not considering whether they were congenital or not, were $1.31 \%$ of the kuril seal and $0.86 \%$ of the larga seal and $11.76 \%$ of the ribbon seal. There were more cases with supernumerary than with missing teeth as Colyer ${ }^{3)}$ observed.

There were more cases of supernumerary teeth in the neighborhood of PC 1, PC 3 and PC 4 than in any other position in the kuril seal and the larga seal (Fig. $1 \mathrm{a}, \mathrm{b}$ ). The differences of the position of supernumerary postcanine teeth between the two species were as follows.

(I) Supernumerary teeth next to PC I stood side by side with PC 1 buccolingually in the kuril seal (Fig. 2) and mesiodistatally in the larga seal (Fig. 3).

(II) The positions of supernumerary postcanine teeth are more variable in the kuril seal than in the larga seal. In the larga seal, supernumerary postcanine teeth in the lower jaw were not found, unlike the kuril seal (Fig. 1 a, b).

Five skulls of the kuril seal, three of the larga seal and one of the ribbon seal had two or more supernumerary postcanine teeth. In these cases, two of the kuril seal and all of the larga seal had two supernumerary teeth

Table 1 Number and percentage of specimens with supernumerary postcanine teeth

\begin{tabular}{llccc}
\hline species & sex & $\begin{array}{c}\text { No. of } \\
\text { specimens } \\
\text { observed }\end{array}$ & $\begin{array}{c}\text { No. of specimens } \\
\text { with supernumerary } \\
\text { postcanine teeth }\end{array}$ & percentage \\
\hline kuril seal & male & 137 & 8 & 5.48 \\
& female & 146 & 12 & 8.22 \\
& unknown & 22 & 0 & 0 \\
total & 305 & 20 & 6.56 \\
& male & 41 & 2 & 4.88 \\
& female & 45 & 3 & 6.67 \\
& unknown & 30 & 2 & 6.67 \\
ribbon seal & total & 116 & 7 & 6.03 \\
& male & 18 & 0 & 0 \\
& female & 14 & 4 & 28.57 \\
& unknown & 2 & 0 & 0 \\
& total & 34 & 4 & 11.76 \\
\hline
\end{tabular}


1a KUAIL SEAL

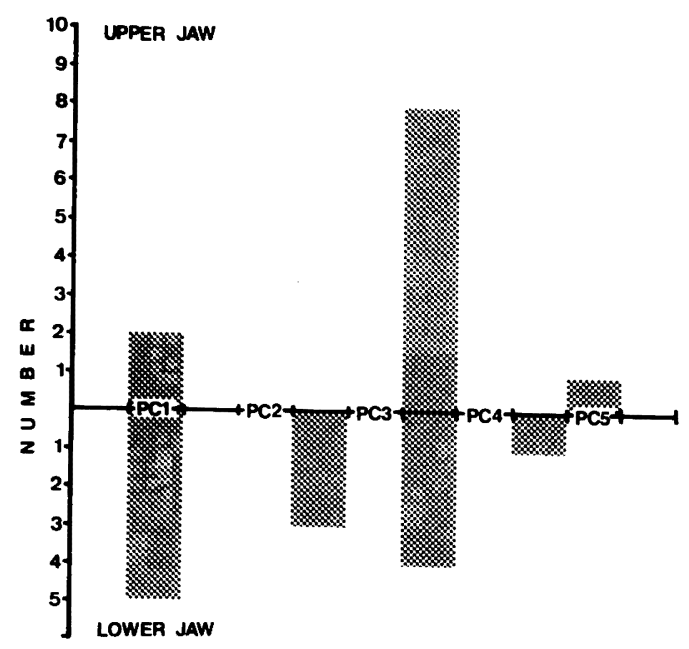

Ib LARGA SEAL

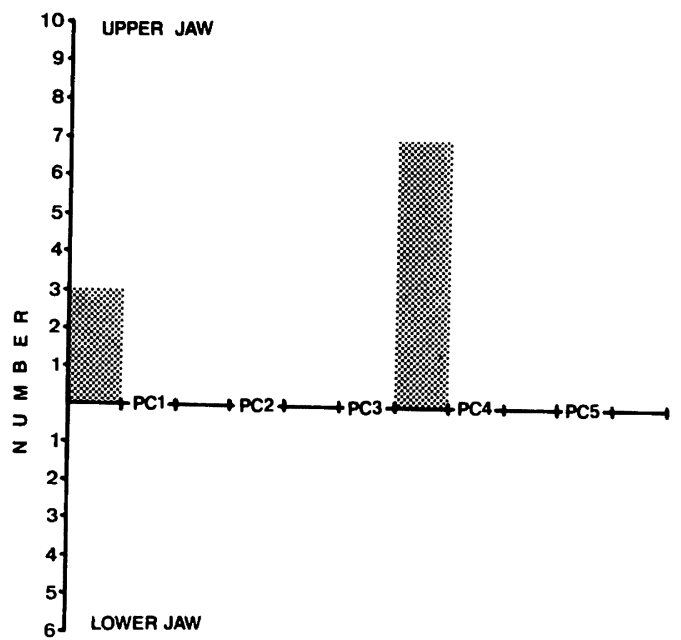

Fig. $1 \mathrm{a}, \mathrm{b}$ The number and position of supernumerary postcanine teeth. As is indicated more supernumerary teeth were found in the neighborhood of PC1, PC 3 and PC4 rather than any other position. In the larga seal (1b), superumerary teeth were found only in the position of the mesial side of PC1 and between PC3 and PC4 on the upper jaw, unlike that of the kuril seal (1a).

which stood in the neighborhood of PC 3 or PC 4 in two of the jaw quadrants (Fig. 4). Three skulls of the kuril seal were different, one had two supernumerary teeth which stood next to PC 1's on each side of the upper jaw, another had two teeth between PC 2 and PC 3 on the lower right jaw, and the third (specimen No. N-224) had three supernumerary teeth. In this latter specimen, two teeth stood between PC 3 and PC 4 on each side of the upper jaw and another tooth stood on the buccal side of the right lower canine (Fig. $5 \mathrm{a}$ ). This tooth had a well developed main cusp and root just as in the canine, and had a developed accessory cusp and a cingulum similar to the postcanine tooth (Fig. $5 \mathrm{~b}$ ). Although one of the ribbon seals had two supernumerary postcanine teeth, we did not judge their position because of the difficulty mentioned previously. skulls with four or more supernumerary postcanine teeth were not found in this collection.

\section{Discussion}

The difference as indicated in (I) probably stemmed from the crowding of the postcanine teeth. As the crowding in the kuril seal is more remarkable than in the larga $\mathrm{seal}^{\mathrm{B})}$, it is thought that the supernumerary teeth next to PC 1 cannot stand mesiodistally in the kuril seal.

Atavism is a reversion to an ancestral character state not evident in recent generations, possibly due to the genes of the ancestral species $^{9}$. Therefore, if atavism is the cause of the supernumerary teeth, these teeth should stand in the precise positions where the teeth, which have become lost in the present species, stood in the ancestral species ${ }^{2}$. In this study, as the positions of the supernumerary postcanine teeth were too variable, it is difficult to imagine the cause to be due to atavism in the kuril seal and the larga seal. It is thought therefore that the cause of supernumerary postcanine teeth is due to a splitting of the tooth germ in these seals. Also in the Canidae, in which comparatively many cases of supernumerary teeth are found in the positions near $\mathrm{P} 1$ and $\mathrm{P} 3$ or $\mathrm{P} 4^{5,10-14}$, Harada et al. ${ }^{13)}$ thought that the supernumerary teeth in the positions of the premolars, is not due to atavism because the Canidae has all four premolars.

The differences (II) between the kuril seal and the larga seal is interesting from the view point of heterochrony. Although the kuril 

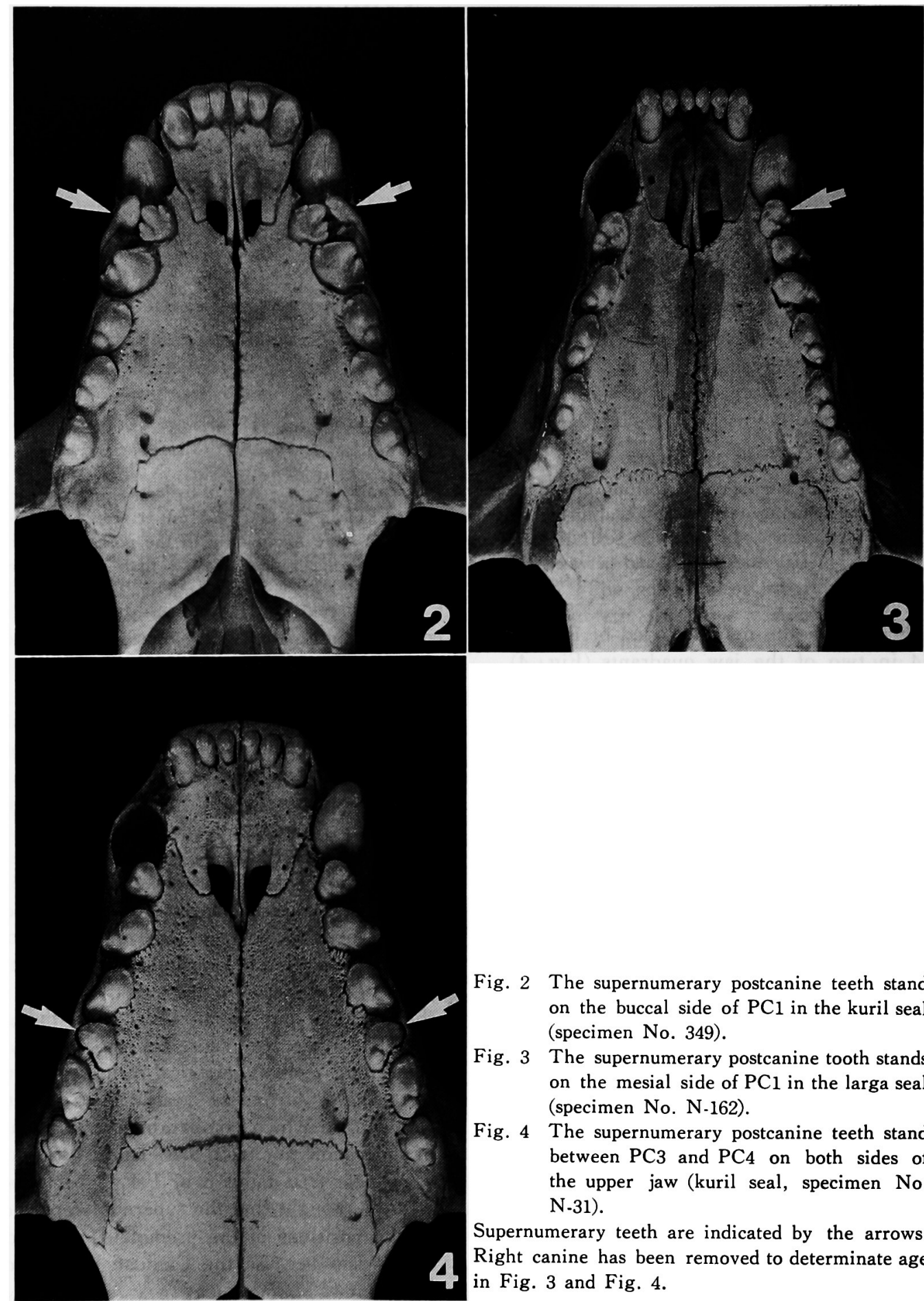

Fig. 2 The supernumerary postcanine teeth stand on the buccal side of $\mathrm{PC} 1$ in the kuril seal (specimen No. 349).

Fig. 3 The supernumerary postcanine tooth stands on the mesial side of $\mathrm{PC} 1$ in the larga seal (specimen No. N-162).

Fig. 4 The supernumerary postcanine teeth stand between PC3 and PC4 on both sides of the upper jaw (kuril seal, specimen No. N-31).

Supernumerary teeth are indicated by the arrows.

Right canine has been removed to determinate age in Fig. 3 and Fig. 4. 


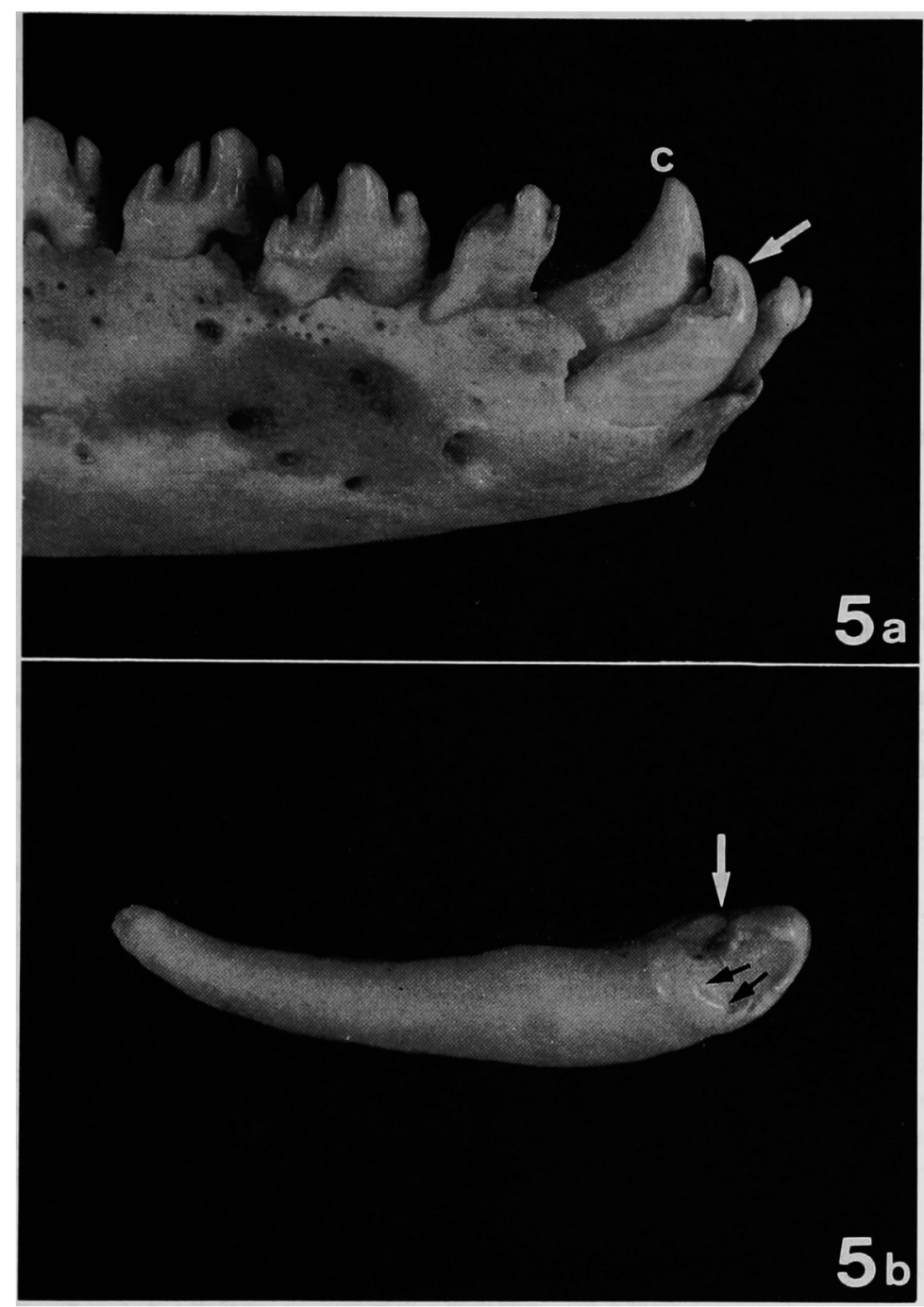

Fig. $5 \mathrm{a}, \mathrm{b}$ The buccal side of the right mandible in specimen No. $\mathrm{N}$.224 kuril seal. The supernumerary tooth, indicated by the arrow, stands on the buccal side of the canine which is marked with " $\mathrm{C}$ " (5a). $5 \mathrm{~b}$ shows the well developed accessory cusp (indicated by the white arrow) and cinglum (indicated by the black arrows) in this tooth.

seal and the larga seal are very closely related systematically, there are many ecological differences between two species ${ }^{15-17}$. The kuril seal gives birth to her pup on the rocks of the seashore and the pup can swim as soon as it is born. Under water lactation is often observed and the pup eats small fishes after being weaned. On the other hand, the larga seal breeds on the pack ice, the new born pup has a white coat and cannot swim properly. The weaned pup eats krill.

$\mathrm{Uno}^{18}$ made a comparative study of skulls between the kuril seal and the larga seal. He pointed out that the kuril seal has a larger skull which had further advanced in the developmental stage than those of the larga seal, and this difference has already appeared in the pup. Uno suggested that the difference in the skulls between two species begins to appear in the foetal stage and is connected 
with the ecological differences mentioned above.

Fujita" said that in the human, the position of many cases of supernumerary tooth are found in the same position where teeth germs are sparse. This is one of the reasons from the bases of Fujita's "splitting of the tooth germs" theory because he thought that the wide space between tooth germs permit the splitting of the tooth germs easily than narrow spaces. If the same is true for the seals, then possibly the foetal development of the maxilla and mandible would be more accelerated in the kuril seal and thus the tooth germ becomes sparse in the kuril seal rather than in the larga seal. As a result of this phenomenon, the supernumerary postcanine teeth would appear in more variable positions in the kuril seal. This hypothesis is not inconsistent with Uno's suggestion ${ }^{18)}$ in which the difference in the skulls between the kuril seal and the larga seal begins to appear in the foetal stage. Taking into consideration that many supernumerary postcanine teeth were in the mandible of the kuril seal, but not in the larga seal, it suggests that there are some kind of differences in the process of accelerated development between the maxilla and the mandible in the kuril seal. To verify this hypothesis, it is necessary to investigate the foetal development process in the kuril seal and the larga seal.

Concerning the case of specimen No. N224 , the supernumerary tooth, which stands on the buccal side of canine, bears the shapes of both the canine and the postcanine teeth. Therefore, this tooth would have stood originally between canine and PC 1 , and have been moved by the position, shape and inclination of other teeth. Although a case of a seven years old northern elephant seal with a milk canine remaining bound to the surface of a permanent canine has been reported ${ }^{19}$, in our case, the tooth is too large and developed to be considered a milk tooth.

Finally, there are many remaining problems concerning the study of the supernumerary postcanine teeth in the ribbon seal. For example, the cause of the high percentage of females with supernumerary teeth is not yet clear. In order to solve these problems, in the future, the position of the supernumerary teeth must be judged.

\section{Acknowledgments}

We are deeply grateful to $\mathrm{Mr}$. T. Itoo (Asahi University) and Professor R. W. Fearnhead (Tsurumi University). Mr. Itoo not only permitted us to examine specimens in his care but also gave us advice. Professor Fearnhead read our manuscript and made us helpful suggestions. We also thank Mr. N. Hachiya and Miss J. Terazaki for assisting us throughout this study.

抄録：ゼニガタアザラシ（Phoca vitulina stejnegeri）305例，ゴマフアザラシ (phoca largha) 116例，ク ラカケアザラシ（Phoca fasciala）34例を用いて煩歯部の過剩歯について検索したところ，それぞれ6.56\%， $6.03 \%, 11.76 \%$ の出現率を示した。一方，欠歯は1.31\%，0.86\%，11.76\%に認められた。ゼニガタアザラ シとゴマフアザラシとでは，過剩歯は欠歯よりも高率で出現しており，哺乳類の中では例外的な現象を示し た。過剩歯は第 1 煩歯および第 $3 ， 4$ 煩歯の付近に多く出現していた。これらの部位を考虑すると，過剩歯 出現の要因は「先祖がえり」とするより「歯胚の異常分裂」とする方が妥当と考えられた。また，ゼニガ夕 アザラシとゴマフアザラシとでは, 過剩歯の好発する部位が異なっていた。これは, 出生後の生態学的特徴 の差異に関連する, 胎仔期の頭蓋骨発達過程の違いに起因するものと思われた。

\section{Referencs}

1) Fujita, T.: Abnormality of tooth number in human. J. Jap. Stomatol. Soc. 25 : 97-106, 1958, (in Japanese).

2) Wolsan, M.: The origin of extra teeth in mammals. Acta Theriol. 29 : 128-133, 1984.

3) Colyer, F.: Variations and disease of the the teeth of animals, pp. 110-113, John Bale, Sons \& Danielsson LTD., London, 1936.

4) Burns, J. J. and F. H. Fay: Comparative morphology of the skull of the ribbon seal with remarks on systematics of the Phocidae. J. Zool. Lond. 161 : 363-394, 1970.

5) Hall, E. R.: Supernumerary and missing teeth in wild mammals of the orders Insec. 
tivora and Carnivora. J. Dent. Res. 19 : 103143, 1940.

6) Scheffer, V. B.: Dentition of the ribbon seal. Proc. Zool. Soc. Lond. 135 : 579-585, 1960.

7) King, J. E. : Seals of the world, pp. 163166, Oxford Univ. Press, London, 1983.

8) Ooё, T. and S. Esaka : Le chevauchement des dents jugales chezles phoques : modalités et évolution postnatale. Mammalia 45 : 497503, 1981, (in French).

9) Lincoln, R. J., G. A. Boxshall and P. F. Clark: A dictionary of ecology, evolution and systematics, pp. 23, Cambridge University Press., Cambridge, 1982.

10) Arnall, L.: Some aspect of dental development in the dog. J. small Anim. Pract. 2: 195201, 1961.

11) Asahi, M. and M. Mori : Abnormalities in the dentition of the racoon dog. Zool. Magaz. 89 : 61-64, 1980. (in Japanese).

12) Buchalczyk, T., J. Dynowski and S. Szteyn : Variations in number of teeth and asymmetry of the skull in the wolf. Acta Theriol. 26 : 23-30, 1981.

13) Harada, Y., H. Imoto, H. Yamada, T. Yamamoto and T. Yamada : Supernumerary teeth in anterior molars of racoon dogs. Jap.
J. oral Biol. $21: 309-316$, 1979. (in Japanese).

14) Hata, R., : On the variation in number of the tooth and root in Nyctereuutes procy. onoides albus. Jap. J. oral Biol. 14 : 118-122, 1972. (in Japanese).

15) Itoo, T., H. Kato and K. Wada: Preliminary study of stomach contents of kuril seal along the eastern coast of Hokkaido, Japan. J. Mammal. Soc. Jpn $9: 285-290$, 1983.

16) Kato, H.: Food habits of larga seal pups in the pack ice area. Sci. Rep. Whales Res. Inst. 34 : 123-136, 1982.

17) Naito, Y. and M. Nishiwaki : The growth of two species of the harbor seal in the ad. jacent waters of Hokkaido. Sci. Rep. Whales Res. Inst. 24 : 127-144, 1972.

18) Uno, H.: Comparison of cranial growth and development between kuril and larga seal. in Ecology and protection of the kuril seal (edited by Wada, K., T. Itoo, A. Niizuma, S. Hayama and M. Suzuki), pp. 158-178, Tokai Univ. Press, Tokyo, 1986. (in Japanese).

19) Briggs, K. T.: Dentition of the northern elephant seal. J. Mammal. 55 : 158-171, 1974. 